William Randolph Hearst Foundation, brought two high school student leaders from each state to Washington, D. C., for the week of January 27 to February 1. While in the Nation's Capital, the students met with the President, members of both Houses of Congress, and the Secretary of State, among others, and participated in a wide range of educational activities-including seminars conducted by political scientists and other experts in government and politics. Comment in the Senate and elsewhere on this program was uniformly favorable.

Regional Political Science Seminars. Through new grants from the Edgar Stern Family Fund and the Rockefeller Foundation, the Association will be able to broaden the scope of the Regional Political Science Seminar Programs, allowing more teachers in the smaller colleges and universities to participate. One-week seminars, conducted by leading scholars and researchers, were scheduled at the University of Tennessee, Knoxville, beginning June 2, and at the University of Nevada, Reno, beginning August 18.

Public Affairs Reporting Awards. The Association also will hold two seminars this fall for winners of the Public Affairs Reporting Awards, competition for which is open this year to political writers in the East and Mid-West.

1963 World Tour-Seminar Program. After four months of negotiations, January to April, the Association completed arrangements-air travel and hotel reservations, provision for study and sightseeing opportunities-for the World TourSeminar. About 80 members reserved seats for departure from San Francisco on August 1, with all air travel on flights operated by major international airlines. Visits were planned in 13 countries, where the Association has arranged briefings and interviews with important government officials in cooperation with the U. S. State Department and the Embassies of the respective nations involved.

Corwin Award. To honor one of America's most distinguished constitutional authorities, the American Political Science Association has agreed to establish an annual Edward S. Corwin A ward.

The award is to be administered by the American Political Science Association and is to be given for the best published work during the year in the field of public law, broadly defined to include the judicial process, judicial biography, judicial behavior, courts, law, legal systems, the American Constitutional system, civil liberties, or any other substantive area, or any work which deals in a significant fashion with a topic related to or having substantial impact on the American Constitution.

To support a prize consistent with the contributions of Professor Corwin and the dignity of the subject will require a trust fund of at least $\$ 15,000$. In view of the large number of persons who have profited from the works of Professor Corwin such a fund should not be difficult to secure. Pledges will be accepted and payments may be made over a period of time.

Checks should be made payable to the American Political Science Association-Corwin Award, 1726 Massachusetts Avenue, N.W. Washington 6, D. C. Contributions are deductible for federal income tax purposes.

\title{
PROFESSIONAL CONFERENCES
}

The Second Annual Rocky Mountain-Great Plains Peace Research Conference was held at Colorado State University, October 13 and 14. Principal speakers of the Conference were: Dr. Harold Taylor, Peace Research Institute; Dr. Robert Matteson, deputy director for planning, United States Arms Control and Disarmament Agency; Dr. Thomas Milburn, chief, Behavioral Science Research Group, China Lake, California; and Dr. George Reinsford, director of university development, University of Denver.

The Conference was organized around disciplinary workshops, including a political science workshop, chaired by Dr. J. Leo Cefkin, Colorado State University. The workshop heard the following papers: "The Price of Peace," by Robert Stevenson, Idaho State College; "Social and Political Orientations of Law Students in Japan," by Yasumasa Kuroda, Montana State College; "The Place for Traditional Scholarship in Peace Research," by Neal D. Houghton, University of Arizona; "Current Research at the Stanford
Studies in International Conflict and Integration," by Ole Holsti, Stanford University; and "The Court of Justice of the European Communities: Contributing Factor to International Peace," by Werner J. Feld, Moorhead State College.

The department of political science at Arizona State University in conjunction with the departments of military science and mass communication held a conference on "The PoliticalMilitary Defense of Latin America" on December 7-8, 1962. Participants included: Professor Ross A. Gomez, University of Arizona, Professor Russell H. Fitzgibbon, University of California at Los Angeles, Professor William P. Cochran, Jr., American Institute of Foreign Trade, Professor James L. Busey, University of Colorado, Professor Roland Hilton of Stanford University and Professors Marvin Alisky, Bruce Mason, John Martinez, Theodore Wyckoff and Arnold Tilden of Arizona State University. 
Stetson University held an institute on Southeast Asia February 6-8 with three guest lecturers participating in the lectures and discussions. The participants were Professor William C. Johnstone of the Johns Hopkins School of Advanced International Studies, Professor Lucian Pye of MIT, and Dr. Nguyen Phu Duc of the Vietnamese Embassy.

The institute was part of a cooperative venture by four mid-Florida colleges and was made possible by a grant from the Danforth Foundation. Comparable institutes were held at the same time on the other three campuses (Rollins, Florida Southern, Florida Presbyterian). Next year the theme of the Institute will be "China and India in Crisis."

The thirty-ninth session of the Institute of World Affairs was held December 2-5, 1962, at the Huntington-Sheraton Hotel in Pasadena under the direction of J. William Robinson of Whittier College.

Professor Robinson chose the theme "Commitment to Freedom" for the thirty-ninth institute, dealing, in his words, with "The Positive Side of the American Record in Foreign Policy." Daily programs had to do with National Goals and the World Around Us, Economic and Social Policy, Policy and Progress in Science, Policy in International Cooperation, and Decisions and Methods.

Chairmen of the daily programs included Chancellor von KleinSmid, Vice President Carl M. Franklin of USC, and Arthur C. Turner of the University of California at Riverside. Evening speakers were Ambassador John M. Allison, now at the University of Hawaii, Sergio Bath of the Brazilian Embassy, General William H. Draper, Assistant Secretary of State Edwin M. Martin, Hans J. Morgenthau, Lt. Col. John A. Powers, General Thomas D. White, and Paul Tillich.

At the thirty-ninth institute papers were read by Willard A. Beling, USC; Ben G. Burnett, Whittier College; Robert S. Gibbs, Boston University; Ronald Hilton, Stanford; Nobutaka Ike, Stanford; President E. Wilson Lyon, Pomona College; Charles A. McClelland, San Francisco State College; Helen Dwight Reid, George Washington University; Franz B. Schick, University of Utah; Dean John M. Swarthout, Portland State College; James T. Watkins, IV, Stanford; and C. S. Whitaker, Jr., University of California at Los Angeles.

The Institute of World Affairs was founded by Chancellor Rufus B. von KleinSmid of the University of Southern California in association with a group of scholars representing the major institutions of the West. Professor James T. Watkins, IV of Stanford University, the director of the fortieth session, which will be held at the HuntingtonSheraton Hotel December 1-4, 1963, has selected "The Grand Design" as the theme of the meeting.

Correspondence with reference to the $1963 \mathrm{In}$ stitute, including suggestions as to interested participants, should be addressed to Paul E. Hadley of the University of Southern California.

The Iowa Conference of Political Scientists held its 1963 annual meeting at Loras College on April 6.

During the morning session Paul Smith of Grinnell College delivered a paper on "Community Power and Influence in East-Central Iowa." Serving as discussants were Donald E. Boles of Iowa State University, Robert Horgan of Clarke College, John C. Norton of St. Ambrose College and Russell Ross of the State University of Iowa.

The afternoon session was devoted to a debate between C. Edwin Gilmour of Grinnell College and State Senator David O. Shaff on "Party Responsibility and Reapportionment in Iowa."

Newly elected officers include: president, Donald E. Boles, Iowa State University; secretary-treasurer, John P. Dorweiler, Loras College; members of the executive committee, Robert Horgan, Clarke College; J. B. Board, Jr., Cornell; Paul Smith, Grinnell; M. W. McMahon, St. Ambrose; N. L. Fadness, Luther College; Robert Boynton, State University of Iowa; Erma Plaehn, State College of Iowa; Charles Clarke, Upper Iowa University.

The 20th Congress of the International Institute of Sociology, originally planned for September, 1962, has now been scheduled to meet September 5-11, 1963 in Cordoba, Argentina, under the auspices of the National University there. Registration fees (\$5) and correspondence concerning participation should be addressed to Professor Alfredo Poviña, Trejo 241, Córdoba, Argentina.

\section{REPORT OF THE STATE DEPARTMENT ADVISORY COMMITTEE ON FOREIGN RELATIONS}

The Committee met on November 2 and 3, 1962 , and examined in detail the problems connected with the series. The gist of its conclusions was that the Foreign Relations series had fallen into serious disarray since 1953. Prior to that time the volumes had been published with fair regularity about fifteen years behind currency (volumes for the 1920 s and early 1930s). Then, at the behest of several influential members of Congress, the Historical Office was required to push ahead 